\title{
ARCHITECTURE AND THE INSCRIPTION OF HISTORY: ORHAN PAMUK'S REPRESENTATION OF ISTANBUL
}

\author{
SAMAR H. ALJAHDALI \\ King Abdulaziz University, Kingdom of Saudi Arabia
}

\begin{abstract}
The city of Istanbul has taken centre stage in the writings of the Turkish novelist, and Nobel-Prize winner, Orhan Pamuk (1952-). In the fictive worlds of his novels, he writes the city and inscribes its peculiar in-between position. This paper aims to sketch out tensions between past and present, conservatism and cosmopolitanism, tradition and modernity. Within the theoretical framework of cultural materialism, this paper investigates Pamuk's Istanbul: Memories of a City (2005), and explores how this tension manifests itself in the architecture of the city. With particular focus on issues of hospitality, cosmopolitanism, and cross-cultural fertilization, I will analyse the textual representation of both the interiors and exteriors of Istanbul, and how they reflect the relationship between self and other. Likewise, museum artefacts bear witness to both the revival and violence of the history of the city from Ottoman times to the present. The analysis will draw on sites of separation as well as those of connection in Pamuk's depiction of Istanbul's material culture.
\end{abstract}

Keywords: Istanbul, cosmopolitanism, cultural materialism, architecture, Orhan Pamuk, Turkish novel, cultural memory, literary representation.

\section{INTRODUCTION}

The city of Istanbul has taken centre stage in the writing of the Turkish novelist, and Noble Prize winner, Orhan Pamuk (1952-). The paper explores the tension that underlies the identity of the modern city, reading its landscape architecture as palimpsest of cultural memory with traces of an historical past and current modernizing actions. The study examines Pamuk's Istanbul: Memories of a City (2003, trans. 2005) sketching ways to understand the connection between architecture and nation-building. I argue that Pamuk's representation of Istanbul reveals a terrain of contestation where two opposing structures of reference intervene and interact in shaping the identity of the city and its inhabitants; namely a cosmopolitan Ottoman Islamic heritage and a nationalist Westernized modern style.

By defining the lieux de mémoire, Pierre Nora offers a useful conceptualization of the relation between memory, landscape and historical change [1]: 'Our interest in lieux de mémoire, where memory crystallizes and secretes itself, has occurred at a particular historical moment, a turning point where consciousness of a break with the past is bound up with the sense that memory has been torn-but torn in such a way as to pose the problem of the embodiment of memory in certain sites where a sense of historical continuity persists. There are lieux de mémoire, sites of memory, because there are no longer milieu de mémoire, real environments of memory' $[1, \mathrm{p} .7]$.

Sites of memory and landscape architecture are powerful agents of memory construction and the inscription of history. Nora's paradigm should be understood in relation to the historical continuity and/or discontinuity created by the intervention of lieux de mémoire, or sites of memory.

With particular focus on the relation between memory and power politics, Aleida Assmann and Linda Shortt argue that memory is a powerful agent of political change [2, $p$. 13]. Exploring the construction and reconstruction of memory at periods of transition, Assmann and Shortt contend that political change enforces a 'reorganization of memory by 
ushering in a new value system,' and cite the 'renaming of streets' among its most obvious signs [2, p. 7].

The erasure and relegation of particular architectural sites are equally significant to understanding the relation between cultural memory and political change. In The Production of Space, Henri Lefebvre argues that 'A monumental work... has a horizon of meaning: a specific or indefinite multiplicity of meanings, a shifting hierarchy in which now one, now another meaning comes momentarily to the fore, by means of - and for the sake of - a particular action... To social practice, the monumental work erases them and replaces them with a tranquil power and certitude which can encompass violence and terror' [3, p. 222].

A monumental work or space articulates narratives and counter-narratives of political and social action, of power and subversion. The concomitant forms of erasure and exposure betray the politics of representation that enable a particular discourse while repressing others. Despite the intervention of power politics in the erasure and replacement of particular meanings, the monumental work communicates the signs of violence and terror that it seeks to hide. I will draw on Pamuk's representation of Istanbul and its material culture to highlight the interplay of power politics in forwarding a particular narrative of the past while erasing alternative stories.

Investigating two of Pamuk's novels, The Black Book (1990, trans. 1994) and Snow (2002, trans. 2004), Rita Sakr reconsiders the political significance of monumentalization in relation to violence and terror [4]. The essay contributes to the critical and ethical engagement with monumentalization in relation to 'terror' and 'taboo' in twentieth-century Turkey, concluding that the political significance of monumentalization emerges not only from its material realization, but also from its reimagining in literary texts [4, p. 247]. This study extends Sakr's argument to the interplay of cosmopolitan discourse and power politics and their reflection on the architecture of the text, more specifically, Pamuk's more recent memoir.

\section{ISTANBUL: MEMORIES OF A CITY}

Pamuk himself studied architecture at the Istanbul Technical University for three years before he decided to change the path of his career and became a writer. Through the literary form of the memoir, Pamuk mobilizes what might be called an authentic memory of Ottoman cosmopolitanism against the formulaic memory of Turkification. By means of both erasure and exposure, Pamuk emphasizes institutional processes implemented directly or otherwise in promoting and demoting particular forms of monumentalization and landscape architecture.

Istanbul, and more specifically the Bosphorus strait, as both a border space and a meeting point, is central to our understanding of cosmopolitanism. Thinking beyond borders, Immanuel Kant adopted cosmopolitanism to conceptualize universal hospitality, transnational mobility, and global peace [5]. For Pamuk, this waterway is different from 'the canals of Amsterdam or Venice or the rivers that divide Paris and Rome in two' [6, p.45]. What makes the Bosphorus different from other European waterways, according to Pamuk, is its specific nature as a point of connectivity rather than a line of separation. The water border represents what Chris Rumford describes as 'prime sites for connecting individuals to the world by creating cosmopolitan opportunities through the possibility of cultural encounters and negotiations of difference' [7, p. 245]. The Bosphorus evolves as architecture of cosmopolitanism opening up possibilities for useful negotiations of the national and international; a defining architecture for 'a sumptuous culture that had been influenced by the West without having lost its originality or vitality' [6, p. 46].

The Bosporus strait is marked by the peculiar architectural style of Yalı (Fig. 1). These seaside buildings, with their wooden structures, pointed arches, and multiple lancet windows, 


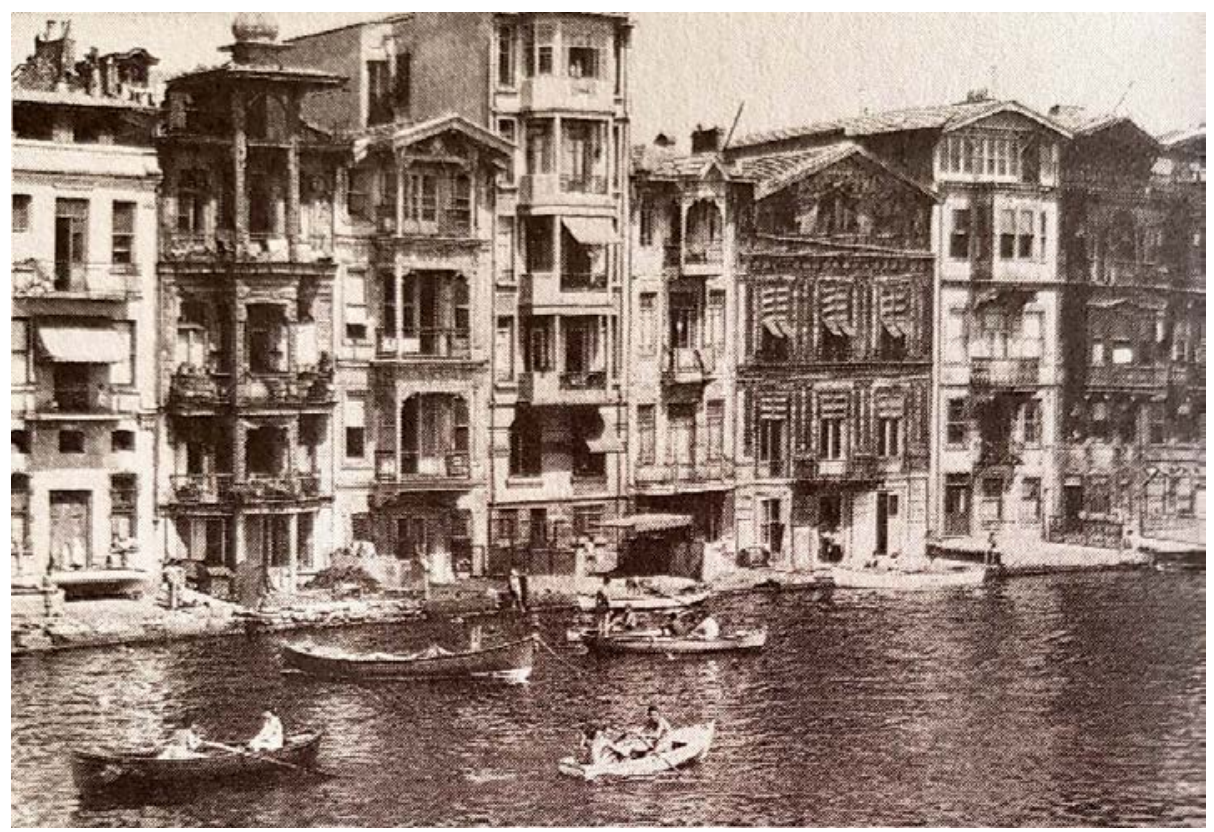

Figure 1: Yalı. (Source: Pamuk, 2006.)

illustrate the cosmopolitan nature fostered by an Ottoman milieu. Being in contiguity with the Bosphorus waterway suggests the openness to mobility and cross-cultural fertilization promoted by the Yalı. While this Ottoman architecture has come to be seen as 'models of an obsolete identity and architecture' [6, p. 43] with the advent of the Republic, it continues to empower its dwellers and visitors with 'the freedom of the open sea' [6, p. 45]. It is this cosmopolitan vibrancy which endows the Bosporus with timeless hope and revivalism: 'if the city speaks of defeat, destruction, deprivation, melancholy and poverty, the Bosphorus sings of life, pleasure, and happiness' [6, p. 43]. It resists confinement and defeat. For Pamuk, this border area has ceased to be a point of separation and rather become a space for connectivity and cosmopolitan opportunities.

Among other influences, Pamuk's cosmopolitan perception is informed by the miniaturist art of the German architect and artist, Antoine-Ignace Melling (1763-1831). The memoir devotes a chapter for Melling, focusing on his miniaturist paintings of the Bosporus with their panoramic views (Fig. 2). These paintings have fascinated Pamuk with how well they capture the complexity and diversity of the city, reflecting what he describes as 'a culture in transition' [6, p. 63]. According to Pamuk, what makes Melling particularly fascinating is his 'fidelity to architectural topographical and everyday details that other Western artists may overcome' [6, p. 62]. His peculiar technique allows him to take in as much details as he needs to complete the logic of the scene. Melling carefully chooses to have a Pera-based gaze, yet maintains a shifting perspective: 'As we survey these landscapes from a lost world, enjoying the fine architectural detail and skilful manipulation of perspective, our desire for verisimilitude is fully satisfied' [6, p. 59]. Pamuk celebrates the cosmopolitan aura of Melling's miniaturist rendering of 'the endless possibilities of Istanbul's geography and architecture' [6, p. 65]. These miniaturist paintings have greatly helped Pamuk in developing a perception of Istanbul as both 'centreless' and 'infinite' [6, p. 60]. 


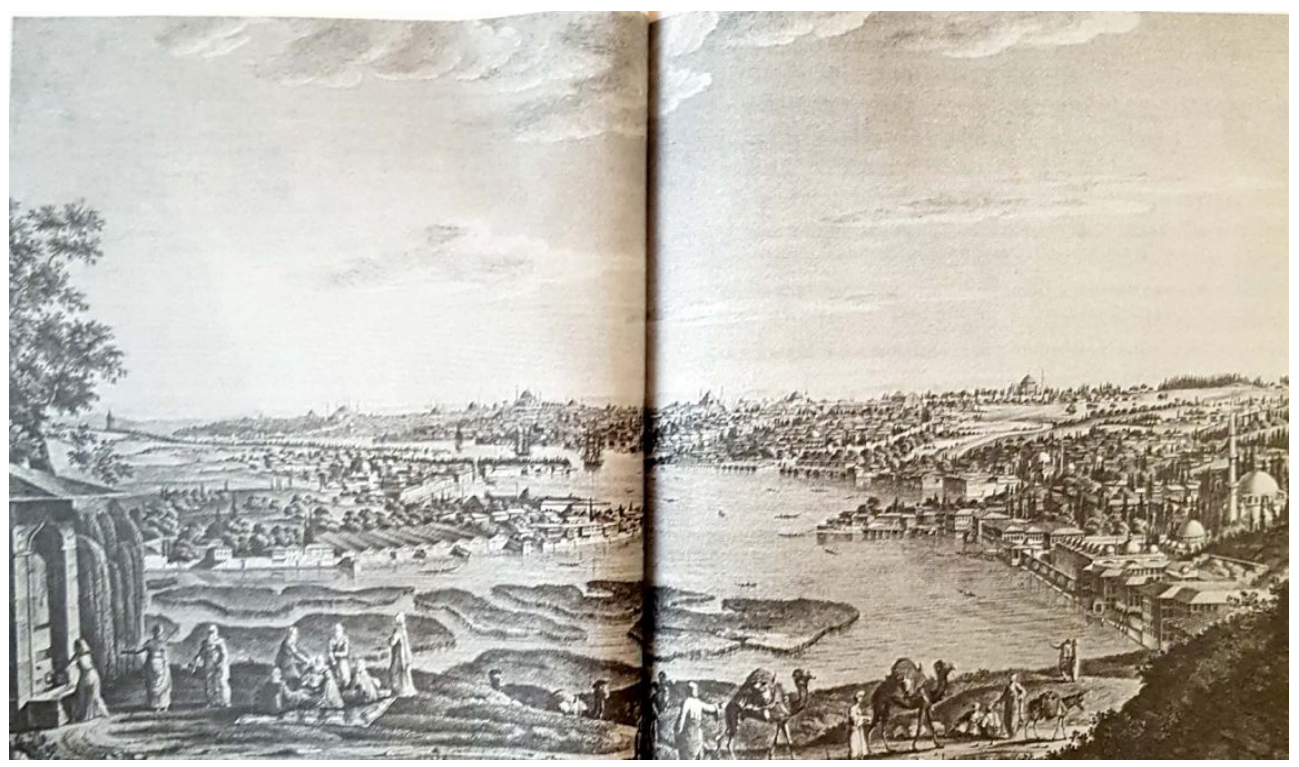

Figure 2: Melling's miniaturist painting. (Source: Pamuk, 2006.)

The Bosphorus is not only a cosmopolitan site, but also a cosmopolitan position of enunciation enabling shifting perspectives and defying univocal perceptions. This border perspective is central to understanding Orhan Pamuk's criticism of a Turkish form of cosmopolitanism, one that pays homage to modernity. Pamuk's cosmopolitan perspective is further supported by the increased mobility of his gaze and the openness of his position of enunciation. For example, according to Pamuk, the ferry is not only a means of transportation but also a way of looking into the world. While studying at the Faculty of Architecture, Pamuk commutes by travelling up and down the Golden Horn on ferries. The cosmopolitan opportunity seems to be at its highest point when the moving ferry passes under the Galata Bridge enabling a graceful view of the multicultural landscape of Istanbul. Pamuk captures this picture in the following description: 'Through the trembling windows in the rear of the ship's upper deck, I watched the Golden Horn's landings slowly flowing past, and its hills covered with the wooden houses of old Istanbul, and its cypress-filled cemeteries: and endless strings of little factories, shops, chimneys, tobacco warehouses, ruined Byzantine churches, the most magnificent Ottoman mosques rising above its dingiest and narrowest streets, alleyways, dark hills, shipyards, rusting hulls of ships' [6, p. 314].

From that position, Pamuk observes how 'the Church of the Pantocrator in Zeyrek' embraces 'the shadow of Fatih Mosque' in a perfect harmony and peacefulness [6, pp. 314, 315].

Seeing from the liberating position of the borderline empowers the viewer with a mode of thinking receptive of mobility while being critical of a monolithic and hegemonic imaginary. To what extent ethos of nation-building and forms of modernity have challenged cosmopolitan orders by delimiting space and creating divisions. Pamuk attributes the demise of a cosmopolitan space in Istanbul to 'the founding of the Republic and the violent rise of Turkification' [6, p. 215]. The establishment of a new concept of Turkishness has brought an end to what was once 'the grand polyglot, multicultural Istanbul of the imperial age; the city 
stagnated, emptied itself out, and became a monotonous, monolingual town in black and white' [6, p. 215]. While waves of migration have contributed to the cosmopolitan past of Istanbul, the accelerating, and often violent, process of cultural homogenization has threatened diversity. By 1950s, non-Turkish groups, including Jews, Armenians, and Greeks escaped marginalization and sought better conditions elsewhere [8, p. 9]: 'The cosmopolitan Istanbul I knew as a child had disappeared by the time I reached adulthood. In 1852, Gautier, like many other travellers of the day, remarked that in the streets of Istanbul you could hear Turkish, Greek, Armenian, Italian, French and English...; noting that many people in this "tower of Babel" were fluent in several languages' [6, p. 215].

The Istanbul Memories of Turkish-Armenian Hagop Mintzuri [8], published posthumously in 1993, 'serves as a timely reminder of the tragic loss of diversity' during the first half of the twentieth century whilst simultaneously signifying emergent tendencies to revive a cosmopolitan milieu [8, p. 8]. In similar veins, Pamuk returns to childhood memories and travellers' writing for a textual resurrection of Istanbul's diversity and multiplicity.

Reading absence as a formative element in the inscription of history, Pamuk traces organized erasures that contributed to the 'cultural cleansing' of Istanbul and the transformation of its identity [6, p. 216]. With the making of the Turkish identity of Istanbul, the introduction of modernity has created rupture in the Ottoman traditions of the city and its historical urban fabric. During the Atatürk era, these measures include the erasure of the Janissaries, the 'slave market', the 'harem', the 'dervish lodges', and the Ottoman clothing [6, pp. 213-214]. Pamuk contextualizes the disavowal of these cultural aspects that have been celebrated in nineteenth-century English and French literary representations of the city, within a dominant 'decline thesis' - to use Ahmet Ersoy description-relating Istanbul to an exotic and oriental heritage [9]. The re-invention of Istanbul as a nationalist, Westernized urban space entails disrupting continuity with an Ottoman Islamic heritage and appropriating Western norms.

An indirect form of erasure can be realized in limiting the visibility of the polyvalent history of Istanbul. The deliberate neglect of monuments that communicate the multi-ethnic culture of Ottoman past illustrates the hegemony imposed on memory. However, the agency of the material culture, albeit absented from the centre, plays a major role in defying silence and obliteration. Pamuk observes: 'No matter how ill-kept they are, no matter how neglected or hemmed in they are by concrete monstrosities, the great mosques and other monuments of the city, as well as the lesser detritus of empire in every side street and corner - the little arches, fountains and neighborhood mosques - inflict heartache on all who live amongst them' [6, p. 91].

Along this line of argument, one should give proper attention to the symbolic significance of the architectural site of the wall in the memoir. Opposite to the connectivity inherent in the Bosphorus and its bridges stands the city wall, with its strong associations of purity and protection, as an internal frontier, necessary for a nation in the making. The Istanbul wall was built in $412 \mathrm{AD}$ during the Byzantine time, and remained intact until the Ottomans broke through this fortification and took control. Istanbul: Memories of a City highlights the duality of its significance in terms of border-making and border permeability. The text recalls Gautier's description of the city wall, which fences off Greek neighbourhoods and relegates them to what came to be the 'Ghetto of Istanbul' [6, p. 208]. However, the penetration of the wall by 'fissures and ravages of time' and by natural flora along with its rupture by the 1894 earthquake have disrupted the durability of this man-made border [6, p. 208] (Figs 3 and 4). Discussing the interplay between cosmopolitanism, modernity, and architecture, Andrew Benjamin argues that the ghetto wall and the city wall define identity, hold it in place, and reinforce the homogenization of the enclosed [10, p. 29]. Within the frame of an emergent 


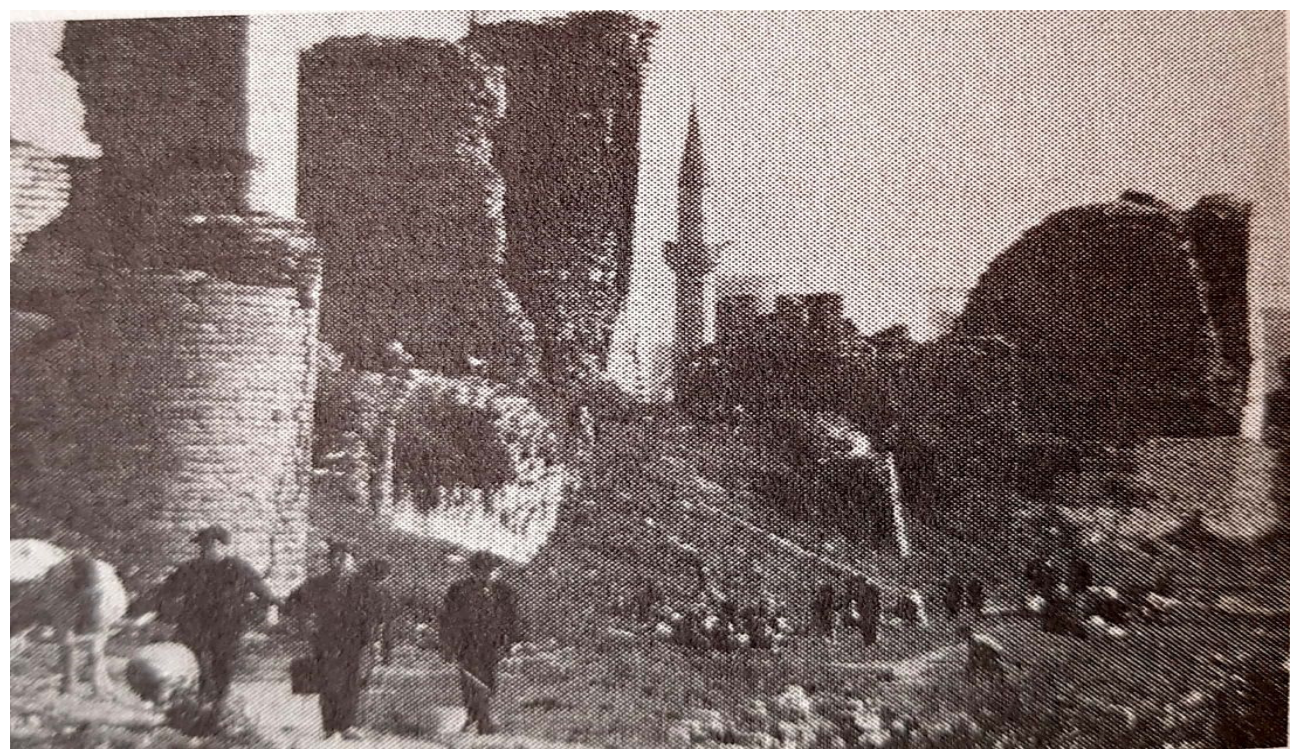

Figure 3: The city wall. (Source: Pamuk, 2006.)

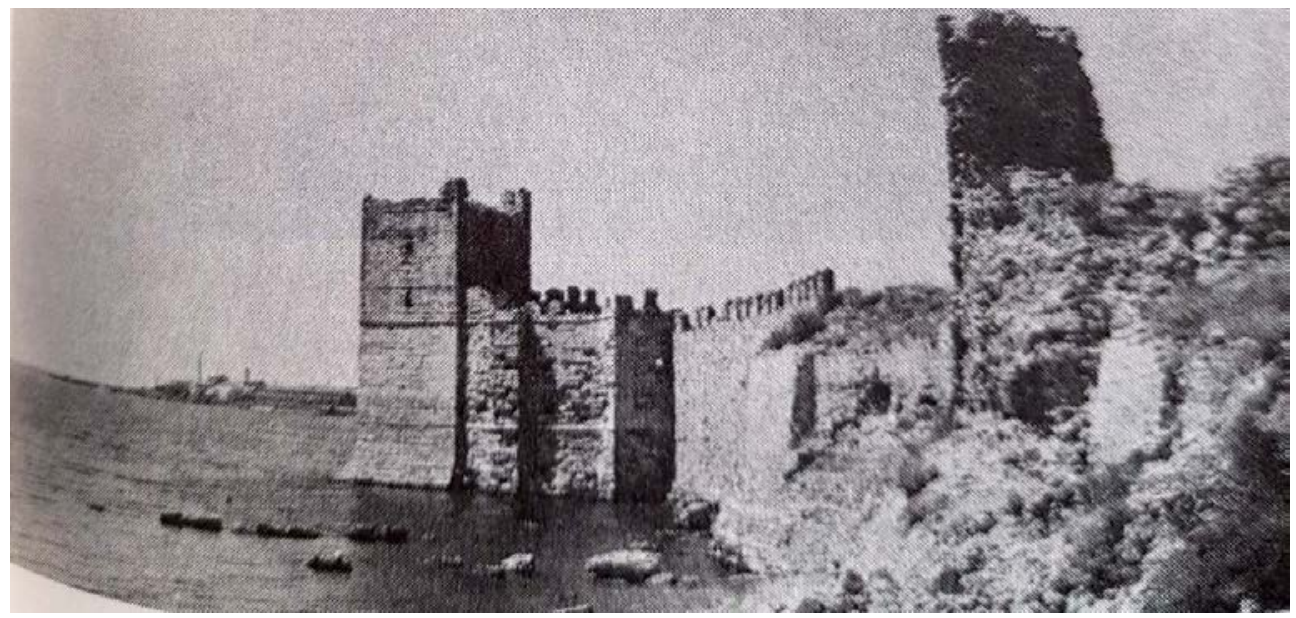

Figure 4: The city wall. (Source: Pamuk, 2006.)

nationalist discourse, Pamuk represents the wall as both an economic and an ethnic border, circumscribing a necessary other against which the Turkish self can be defined. Walking among destitute minorities in the less traversed places outside the city wall, Pamuk returns to the cosmopolitan chronotopes of melancholic ruins.

Pamuk allows space for the marginalized Armenian perspective into the rich fabric of representing Istanbul through the photographs of the Turkish-Armenian Ara Güler. The Intervention of the unsayable helps revive the lost glories of the cosmopolitan past. The memoir opens with a highly significant photograph by Güler. The panoramic view of the 
photograph captures the sublimity of the scene in the Sultanahmet area with Ayia Sophia and the Blue Mosque embracing the skyline against the extended backdrop of the Bosporus, hence promising further connectivity [6, pp. 4-5] (Fig. 5). Although the text makes no reference to the photograph, its embedded dialogism brings together the landscape architecture of the Byzantine and the Ottoman histories. This dialogism, which has long informed the identity of the city, challenges emergent proto-nationalist discourses.

The resonance of the past manifests itself in Pamuk's preoccupation with the idea of the museum and its constructed narratives. In Pamuk's memoir, the living museum of Nișantași and the 'sitting-room museums' articulate densely historical narratives [6, p. 10]. Recounting memories of his childhood, Pamuk describes how the Pamuk Apartment has been built on the ruins of an Ottoman Pasha's mansion. In the superb area of Nișantași, not only the Pamuk family home, but also the schools, where he studied, and the headquarters of the district council, where he received vaccination, were housed in old Pashas' mansions. The hill area of Nișantaşi can be seen as a living museum, telling nostalgic stories of Ottoman history. This rural space has been a destination of repose and recluse for most nineteen-century Ottoman Sultans, abandoning Topkapı Palace and escaping a bustling and tuberculosiscontaminated city. The name Nișantași means a 'target stone' where those Ottoman Pashas used to practice shooting and archery, leaving behind decaying arrows and shattered earthenware pots to tell of their stories [6, p. 24]. The ruins and broken artefacts bear witness to the violence of history and 'end-of-empire melancholy' [6, p. 6]. For the modern visitor, these mansions exist only in ruins, ashes of burned glories, making way for the more Westernized architecture of apartment building.

The sitting rooms of these apartment buildings have become a terrain of contestations, where the dialectic of Westernized and conservative modes prevails. Describing the interiors of his family house, Pamuk comments on the unusual obsession with photographs and the constructed narratives they are meant to communicate; 'sitting rooms were little museums designated to demonstrate to a hypothetical visitor that the house holders were Westernized' [6, p. 10]. However, looking from the widows of these sitting-rooms, memories of Ottoman ruins counteract the imposed narrative of the interior museums pertinent to the making of Turkishness.

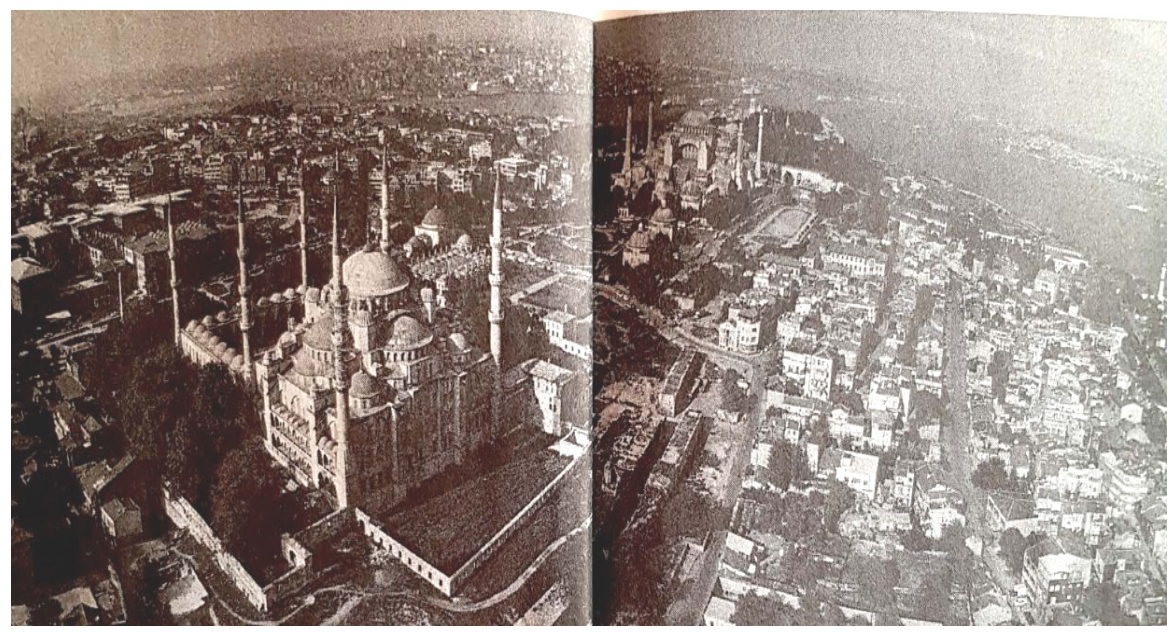

Figure 5: Ara Güler's panoramic photograph of the Sultanahmet area. (Source: Pamuk, 2006.) 
Pamuk's adherence to a cosmopolitan perspective can be realized in the rich dialogism of his memoir. A plethora of Eastern and Western writers, architects, and artists, who have contributed to writing Istanbul, shape the cultural diversity of the text. These voices include Gustave Flaubert, Le Corbusier, Melling, Theophile Gautier, Gerard de Nerval, alongside the Turkish writers, Tanpinar and Yahya Kemal, and Ara Güler, a photographer of Armenian descent, among many others. Despite their desperate socio-historical and cultural backgrounds, these voices intervene and interact in the memoir at a time of rising nationalist affiliations.

In his memoir, Pamuk brings together different configurations of the picturesque in relation to Istanbul as accentuated by diverse writers. The Turkish prose writer, Tanpinar, and the Turkish poet, Yahya Kemal, find the picturesque in the poor neighborhoods outside the city walls. While retaining associations with economic deprivation, featured in Stephen Copley's conception of the picturesque [11], this local perspective turns attention to the 'ruined', 'poor', and 'wretched' landscapes in search for signs of Turkishness [6, p. 227]. As opposed to Ottomans' 'too cosmopolitan' [6, p. 227] forms, the poetics and politics of this local rendition of the picturesque are meant to consolidate the nationalist project. Commenting on Tanpinar and Kemal's cultural practice of walking together in the ruins of unprivileged spaces and their writing of the picturesque experience, Pamuk observes: 'They had a political agenda: they were picking their way through the ruins looking for signs of a new Turkish state, a new Turkish nationalism: the Ottoman Empire might have fallen, but the Turkish people who had made it great (like the state, the two were happy to forget the Greeks, the Armenians, the Jews, the Kurds and many other minorities) and they wanted to show that, though suffused in melancholy they were still standing tall' [6, p. 225].

Their nationalist discourse is made more agreeable than the state's authoritative rhetoric by means of a poetic language.

Pamuk, however, redefines the picturesque in relation to John Ruskin's perception as described in The Seven Lamps of Architecture (1849). For Ruskin, it is history that endows architecture with picturesque beauty, which 'rises out of details that emerge only after the buildings have been standing for hundreds of years, from the ivy, the herbs and grassy meadows' [6, p. 230]. The beauty of this decay is caused by the imprints of history and the intervention of nature in architecture. Newly constructed modernized buildings lack this picturesque beauty.

Pamuk's reinvention of the picturesque can be read within the frame of what Donna Landry has described as 'the geopolitical picturesque.' She argues that the picturesque has attained 'global usefulness,' serving as 'a mode of post-imperial auto-critique' [11, p. 111]. Central to Pamuk's geopolitical picturesque is the restored connection to the imperial past, and more particularly, to Ottoman architecture. Equally important is the 'accidental' intervention of the natural into the built landscape [6, p. 231], suggesting a connection between Ottoman picturesque and the cultural memory of Istanbulites. Pamuk reflects: 'In Istanbul's poor neighbourhoods, however, beauty resides entirely in the crumbling city walls, in the grass, ivy, weeds and trees I remember growing from the towers and walls of the castles of Rumelihisari and Anadoluhisari. The beauty of a broken fountain, an old ramshackle mansion, a ruined hundred-year-old gasworks, the crumbling wall of an old mosque, the vines and plane trees intertwining to shade the old, blackened walls of a wooden house, is accidental' [6, p. 231].

Pamuk notes the centrality of post-imperial historical decay, economic deprivation, and marginalization of minorities to the making of nationalist memory. Pamuk's reinvention of the picturesque while confirming the legacy of the enlightenment with its adherence to 
cosmopolitan ideals, subverts the more recent homogenization of Turkey's nationalist project.

While walking in the village of Eyüp, located at the head of the Golden Horn, Pamuk expresses nostalgia for a lost cosmopolitanism. The history of Eyüp dates back to the Byzantine period through the Ottoman Empire when it was re-named after Abu Ayyub alAnsari. However, the modernization of the village has transformed its cultural identity and deprived it of the 'delicious melancholy' and monumentalizing aura that he has experienced elsewhere [6, p. 320]. Now a tourist attraction, this small village has changed into a 'Turkish Eastern Muslim Disneyland,'- to use Pamuk's description-attracting the French naval officer and novelist, Pierre Loti, known for his exotic novels, to seek residence there. That residence has become a popular café, inviting tourists to enjoy a panoramic view of Istanbul. The very reasons which attract Westerners to reside in that periphery, reshape its architectural remains, and reproduce the place anew, are the reasons that make Eyüp appear so 'irksome' to Pamuk, driving him to redirect his walks in search of authentic ruins: 'I was slowly coming to understand that I loved Istanbul for its ruins, for its huzun, for the glories once possessed and later lost. And so, to cheer myself up, I left Eyüp to wander around other neighbourhoods in search of ruins' [6, p. 320].

The rapid gentrification that the Istanbul district of Pera - today's Beyoğlu, North of the Golden Horn-has undergone illustrates the practice of erasure. In spite of the replacement of the Greek name Pera, by the Turkish name Beyoğlu, Pamuk insists on using the former name, resisting the marginalization of its pre-Turification history. Following the Cyprus conflict, the large Greek population of Pera found themselves forced to leave, but the inscriptions of their history on its landscape architecture remain; 'the Pera neighbourhoods so masterfully built by Armenians that were still standing' [6, p. 311] (Fig. 6). With the sweeping modernization of Pera, these neglected landscape of 'old Greek and Jewish neighbourhoods,' of the 'Muslim, very bright back streets of Üsküdar' with their 1980s wooden houses have been fenced off and ruined by 'hastily constructed and sinister-looking apartment blocks' [6, p. 312]. As Florian Riedler notes, 'the shopping malls, cafes, restaurants, and pubs in the inner city entertainment district of Beyoğlu have increasingly used its nineteenth century architecture as a stage for consumerism' [8, p. 9]. Pamuk is less interested in this architecture of consumerism than in the cosmopolitan opportunities offered by the palimpsest of its poor neighbourhoods.

Istanbul complicates the cosmopolitan paradigm. Pamuk reads the reinvention of Turkish cosmopolitanism by observing the mediation of Istanbul's material culture and landscape
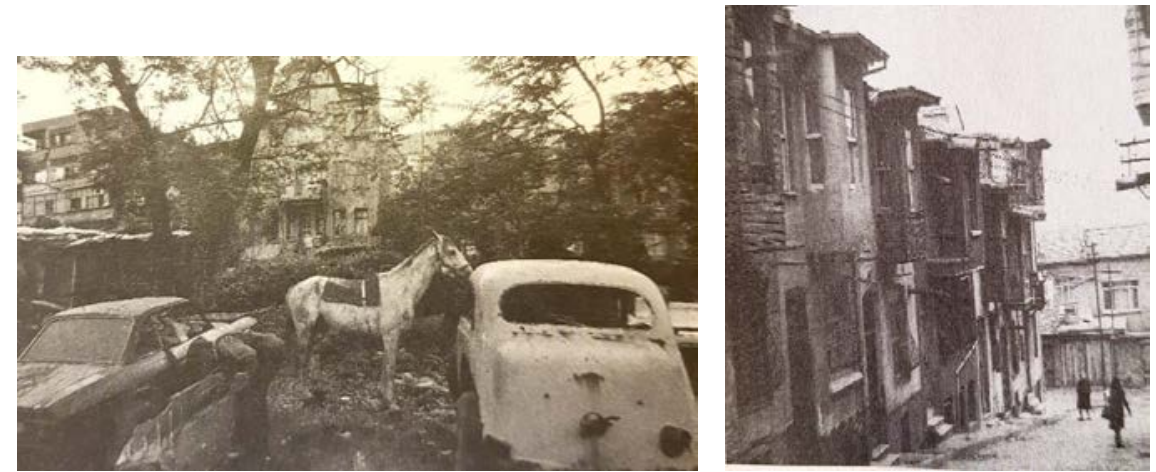

Figure 6: The Pera neighbourhood of the past. (Source: Pamuk, 2006.) 
architecture. The memoir reveals Pamuk's criticism of what might be called 'minimal cosmopolitanism' in which elements of cosmopolitanism are combined with elements of nationalism [12, p. 374]. Here, cosmopolitan tenets are reconciled in accordance with nationalist aims. Informed by the ideology of nation-building, Turkey's minimal cosmopolitanism neglects the authentic multi-ethnic space of Ottoman past, whilst simultaneously celebrating a predominantly Western urbanism. The latter is defined by the foreign imprints of Italian, German and French architects on the city's architecture landscape, resulting in what came to be Turkey's modern reconfiguration of cosmopolitanism.

Pamuk, the flanuer, storyteller, and artefact collector negotiates the politics and poetics of Istanbul's peculiar position amid diverse, and often conflicting, histories, spacialities, and cultures. Istanbul: Memories of a City offers an exploration of the interrelatedness of material culture and political change in shaping and reshaping cultural memory. By adjusting the focus of his lens to capture the peripheral and outside the city wall area, he has 'discursively monumentalized' - to use Rita Sakr's words [4] — these forgotten spaces where a meaningful cosmopolitan setting resists nationalist homogenization. In subversion of univocal Turkification of the land, the memoir recovers multi-ethnic ruins from the margins of the city to the centre of the text. Critical of the declining cosmopolitanism of Ottoman times, the representation of Istanbul is made densely vibrant with overlapping chronotopes, as a plethora of walks through the city at distinct times find expression and achieve imaginary cosmopolitanism.

\section{REFERENCES}

[1] Nora, P., Between memory and history: les lieux de mémoire. Representations, 26 (Special Issue: Memory and Counter-Memory), pp. 7-24, 1989.

[2] Assmann, A. \& Shortt, L., (eds.), Memory and Political Change, Palgrave: Basingstoke and New York, pp. 1-14, 2012.

[3] Lefebvre, H., The Production of Space, trans. Donald Nicholson-Smith, Oxford: Blackwell, 1991.

[4] Sakr, R., Between terror and taboo: monumentalisation as the matrix of history and politics in Orhan Pamuk's the Black Book and Snow. British Journal of Middle Eastern Studies, 38(2), pp. 227-247, 2011.

[5] Kant, I., Perpetual Peace and Other Essays on Politics, History, and Morals, trans. Ted Humphrey, Hackett: Indianapolis, 1983.

[6] Pamuk, O., Istanbul: Memories of a City, trans. Maureen Freely, Faber and Faber: Kent, 2006.

[7] Rumford, C., Bordering and connectivity: cosmopolitan opportunities. Routledge Handbook of Cosmopolitanism Studies, ed. Gerard Delanty, Routledge: Abingdon and New York, pp. 245-253, 2012.

[8] Riedler, F., Rediscovering Istanbul's cosmopolitan past. Everyday Cosmopolitanism, ISIM Review, 22, pp. 8-9, 2008.

[9] Ersoy, A., Architecture and the Late Ottoman Historical Imaginary: Reconfiguring the Architectural Past in a Modernizing Empire, Burlington: Ashgate, 2015.

[10] Benjamin, A., The place of cosmopolitan architecture. Architectural Theory Review, 7(1), pp. 26-36, 2002.

[11] Landry, D., The geopolitical picturesque. Land \& Identity: Theory, Memory, and Practice, eds. Christine Berberich, Neil Campbell, \& Robert Hudson, Rodopi: Amsterdam and New York, pp. 91-114, 2012.

[12] Audi, R., Nationalism, patriotism, and cosmopolitanism in an age of globalisation. The Journal of Ethics, 13(4), pp. 365-381, 2009. 